\title{
Evaluation of the Impact of Platelet Rich Plasma and Hyaluronic Acid on Ketamine-Induced Cystitis in Albino Rats: A Histological and Immunohistochemical Study
}

\author{
Nahla El-Eraky El-Azab, Abeer M. El-Mahalaway, Ola Mostafa
}

Departments of Histology and Cell Biology, Faculty of Medicine, Benha University, Egypt

\begin{abstract}
Background: ketamine induced cystitis (KIC) is commonly occurred in ketamine abusing individuals. It is associated with damage in the lining of the bladder and lower urinary tract symptoms. Platelets rich plasma (PRP) is attractive therapeutic line in regenerative medicine. Hyaluronic acid (HA) has many beneficial therapeutic effects in treatment of different types of cystitis.

Objective: to evaluate the effect of PRP and HA on ketamine induced cystitis in adult male rats.

Materials and Methods: Forty- four adult male rats were divided into five groups: Group I: control rats. Group II: Ketamine group. Group III: Recovery group. Group IV: Ketamine and PRP treated group. Group V: Ketamine and HA treated group. Specimens from the body of the urinary bladder were processed and examined histologically and immunohistochemically. Morphometrical studies and statistical analysis were conducted.

Results: Groups II and III showed focal areas of degeneration and ulceration with apparently decreased thickness of the urothelium. Cellular infiltration and dilated congested blood vessels of the lamina propria were also observed. A significant increase of the collagen fibers in the lamina propria and between the muscle bundles. Nuclear factor kappa B (NF- $\kappa$ B) immunoreaction was significantly increased but there was a non-significant increase of antiproliferating cell nuclear antigen (PCNA) immunopositive nuclei among urothelium and a significant decrease of desmin, compared to group I. Groups III and IV showed improvement of most of the histological and immunohistochemical changes described before.

Conclusion: The intravesical injection of PRP and HA provide a positive impact on treatment of KIC. HA therapy is a more efficient mean as it provides a better improvement in healing of urothelium and promotes more rapid tissue regeneration.
\end{abstract}

Received: 09 November 2019, Accepted: 26 November 2019

Key Words: HA, KIC, PRP.

Corresponding Author: Nahla El-Eraky El-Azab, M.D., Department of Histology and Cell Biology, Faculty of Medicine, Benha University, Benha, Egypt, Tel.: +20 133224400, E-mail: elerakynahla@gmail.com

ISSN: 1110-0559, Vol. 43, No.3

\section{INTRODUCTION}

The urinary bladder is not a vital organ. Its only and main function is storage of urine followed by periodic emptying with time. The bladder urothelium is particularly quiescent and its turnover rate is low about $0.12 \%^{[1]}$.

Cystitis is an inflammatory disease which caused by several etiologic factors, such as bacterial infection, chemicals, exposure to radiation, use of a catheter, or irritating hygiene products, that act through many pathogenic mechanisms ${ }^{[2]}$.

Ketamine is a potent non-competitive receptor antagonist of N-methyl-D-aspartate (NMDA). It is an intravenous anesthetic drug with sedative, analgesic, and anti-depressive effects ${ }^{[3,4]}$.

Ketamine abuse has increased, and its hazardous effects have attracted more and more people's attention ${ }^{[4,5]}$. It may cause serious health problems to many systems as brain, cardiovascular and genital systems. Additionally, it can damage the urinary tract integrity and function leading to ketamine induced cystitis (KIC). The main clinical manifestations of KIC are similar to interstitial cystitis (IC), which include frequency, dysuria, hematuria and a reduced capacity of the bladder ${ }^{[4,6,7]}$.

Various regimens for treatment KIC, mainly symptomatic, have been used, including antibiotics, steroids, non-steroid anti-inflammatory drugs, and anticholinergics. Though, none of the them have an effective and durable results ${ }^{[8]}$.

Platelet-rich plasma (PRP) has become attractive therapeutic option in regenerative medicine for its powerful healing properties ${ }^{[9]}$. Platelet-rich plasma is an autologous derivative of whole blood that concentrates a large number of platelets in a small volume of plasma to be considered "platelet rich". PRP is a rich source of several growth factors. It formed of different quantities of plasma, white blood cells, erythrocytes and platelets according to the device and technique applied ${ }^{[10,11]}$.

It has major advantages compared with other methods on clinical purposes as it is a cheap product, easily obtained, and being autologous diminishes the hazards of 
rejection or immune response. Additionally, PRP has an antimicrobial effect as it contains leukocytes, resulting of diminishing the risk of infection ${ }^{[9,10,12,13]}$.

Hyaluronic acid (hyaluronan or hyaluronate) is a mucopolysaccharide that constitutes of a significant proportion of glycosaminoglycans. It is a major component of extracellular matrix nearly in all living tissues and composed of repeating disaccharides of glucuronic acid and $\mathrm{N}$-acetylglucosamine $\mathrm{e}^{[14,15]}$. It is clinically safe, well-tolerated and possess important tissue healing properties $^{[16,17]}$. Hyaluronic acid (HA) is an alternative therapeutic line for treatment of different types of cystitis as KIC, IC, radiation induced or recurrent bacterial cystitis and also in many degenerative conditions such as osteoarthritis ${ }^{[18,19,20,21]}$.

Our study was planned to evaluate the effect of PRP and HA on ketamine induced cystitis in adult male rats.

\section{MATERIALS AND METHODS}

Forty- four adult male rats weighing 160-220 g each were utilized in this study. Rats were gained from the animal house unit, Moshtohor Faculty of Veterinary Medicine, Benha University, Egypt. They were housed under standard environmental and labo $\neg$ ratory conditions with free supply to water and food. All the experimental procedures were agreed upon by the local ethics committee of the Faculty of Medicine, Benha University.

\section{Used Reagents}

Ketamine (Ketalar; Pfizer, New York, NY) were purchased and injected intraperitoneally to rats in a dose of $30 \mathrm{mg} / \mathrm{kg} / \mathrm{day}$ for four weeks ${ }^{[6,22]}$. Ketalar is a solution contains $10 \mathrm{mg}$ of ketamine $/ \mathrm{ml}$ in $20 \mathrm{ml}$ vial.

Platelet-Rich Plasma (PRP): were prepared at Biochemistry Department, Faculty of Medicine, Cairo University. PRP were injected intravesical in a dose of $1 \mathrm{ml} / \mathrm{rat} /$ day for two weeks ${ }^{[23]}$

Hyaluronic acid; HA (Cystistat; Mylan, Canonsburg, PA) were obtained and injected intravesical to the animals in a dose of $0.5 \mathrm{~mL} / \mathrm{rat} /$ day for two weeks ${ }^{[6]}$. Cystistat is a solution containing $40 \mathrm{mg}$ of hyaluronic acid in a $50 \mathrm{ml}$ vial.

\section{Procedures of Intravesical Injection of PRP and Hyaluronic Acid}

After anesthesia, intravesical injection was performed, via a sterile polyethylene tube (PE-50; Clay-Adams, Parsippany, NJ), which was inserted into the bladder through the urethra. The lower abdomen was pressed gently to help the urine aspiration. Then, PRP or hyaluronic acid were injected with one $\mathrm{mL}$ syringe through the transurethral tube and each was retained in the bladder for $30 \mathrm{~min}$ after installation ${ }^{[6,23]}$.

\section{Experimental Design}

\section{Rats were Arranged in toFive Groups}

Group I (control group) ( $\mathbf{n = 1 2}$ ): rats were subdivided equally into three subgroups. Subgroup Ia: rats were left without any intervention. Subgroup Ib: rats were injected intraperitoneal daily with $0.5 \mathrm{ml}$ of $0.9 \%$ saline for four weeks; Subgroup Ic: rats were injected intraperitoneal daily with the $0.5 \mathrm{ml}$ of $0.9 \%$ saline, then daily intravesical injection of $0.5 \mathrm{ml}$ saline for another two weeks.

Group II (Ketamine group) (n=8): rats were injected intraperitoneal daily with ketamine for four weeks.

Group III (Recovery group) $(\mathbf{n}=\mathbf{8})$ : rats were injected daily with ketamine for four weeks and then left without treatment for another two weeks.

Group IV (Ketamine and PRP treated group) $(n=8)$ : rats were injected with ketamine as described in group II; then injected daily intravesical with PRP for another two weeks.

Group V (Ketamine and HA treated group) $(n=8)$ : rats were injected with ketamine as in group II; then injected daily intravesical with HA for another two weeks.

Rats of subgroup Ib, and group II were sacrificed after four weeks, while those of the other groups were sacrificed after six weeks from the beginning of experiment.

\section{Preparation of Platelet-Rich Plasma (PRP)}

The PRP was prepared using the double centrifugation tube method ${ }^{[24]}$. Fresh venous blood was collected from the jugular veins of healthy male rats and treated with sodium citrate anticoagulant. The blood containing tubes were centrifuged at 1700 revolutions per minute (rpm) for about ten min. The blood differentiated into three different density components; the upper one contained plasma and platelets, RBCs were at the bottom, while in-between there was a buffy coat of leucocytes. A cellular plasma was pipetted and transferred into new tube which centrifuged again at $2000 \mathrm{rpm}$ for $15 \mathrm{~min}$. Plasma centrifugation resulted into a supernatant of platelet-poor plasma (PPP) and the platelet pellet. Platelet-poor plasma were removed, and the platelet pellets were suspended in 3-5 $\mathrm{ml}$ of plasma to produce the PRP.

\section{Histological Studies}

Specimens from the body of the urinary bladder were fixed in $10 \%$ formalin for 48 hours. Paraffin sections (5- $\mu \mathrm{m}$-thick) were prepared, processed and stained with hematoxylin \& eosin for the histological details of urinary bladder and with Masson's trichrome for collagen ${ }^{[25]}$.

\section{Immunohistochemical Studies}

Other urinary bladder sections were mounted on positively charged slides for immunohistochemical staining ${ }^{[26]}$ 
1. Nuclear factor kappa $B(N F-\kappa B)$ is an indicator of inflammation. The primary antibody used was rabbit polyclonal antibody against NF- $\mathrm{BB}$ (Labvision, Fremont,California, USA). NF- $\kappa \mathrm{B}$ immunoexpression is brown nuclear/cytoplasmic staining.

2. Antiproliferating cell nuclear antigen (PCNA), is an indicator of cellular proliferation. The primary monoclonal antibody used was anti-PCNA IgG antibody (Sigma-Aldrich Inc., U.K.). PCNA immunoexpression appeared as brown nuclear staining.

3. Desmin: the primary antibody, monoclonal antiDesmin (DE-R-11), (Ventana Medical Systems, Tucson, Arizona, USA). Intermediate filaments of desmin were stained brown (cytoplasmic).

Immunohistochemical studies were conducted using the avidin-biotin peroxidase method. Diaminobenzidine (Dakopatts, Glostrup, Denmark) was used as a chromogen. The slides were counterstained with hematoxylin. For the negative control, the specific primary antibody was replaced by phosphate-buffered saline. The positive control for NF kappa, PCNA and desmin were sections from prostatic carcinoma, skin and uterus respectively.

\section{Morphometric Analysis}

Morphometric studies were performed by means of a Leica Qwin 500 image analysis computer system (Leica Microsystems Ltd., Cambridge, UK) at the Pathology Department, Faculty of Medicine, Cairo University. Eight slides from different rats of each group $(n=8)$ were evaluated. The mean area percentage of collagen fibers as well as the areas occupied by positive immunoexpression of NF kappa $\mathrm{B}, \mathrm{PCNA}$ and, desmin were assessed in 10 nonoverlapping fields of each section at $\times 400$ magnification.

\section{Statistical Analysis}

All the data collected from the experiment was recorded and analyzed using IBM SPSS Statistics software for Windows, Version 20 (IBM Corp., Armonk, NY, USA). One-way analysis of variance (ANOVA) with Post Hoc LSD test was applied to compare differences among the groups. The data was expressed as $t$ mean $(\mathrm{M})$ value \pm standard deviation (SD) and differences were considered significant at $P<0.01$.

\section{RESULTS}

\section{$H \& E$ Stain}

Group I: Urinary bladder sections from all control subgroups showed normal histological architecture. Its wall was formed of highly folded mucosa, which was lined by transitional urothelium with underlying lamina propria and smooth muscle bundles. Epithelial lining was formed of superficial umbrella-like cells bulging into the lumen with abundant eosinophilic cytoplasm. The intermediate cells were smaller with ample cytoplasm and oval nuclei.
The cuboidal basal cells rested on a basement membrane. The lamina propria is dense collagenous and contains a number of lymphocytes (Figures1a \& 1b). Smooth muscle bundles running in different directions were observed. The muscle fibers have central vesicular nuclei and acidophilic cytoplasm. The bundles were separated by connective tissue (Figure 1c).

Groups II and III: sections showed the same histological results. There were focal areas of degeneration and ulceration with apparently decreased thickness of the transitional epithelium. The urothelium also revealed vacuolization with darkly stained pyknotic nuclei of most cells and some karyolitic ones. In addition, the lamina propria was disturbed with wide spaces, inflammatory cell infiltration and dilated congested blood vessels (Figures $2 \mathrm{a} \& 2 \mathrm{~b} \& 2 \mathrm{c}$ ). The smooth muscle bundles were seen and some of them were degenerated leaving wide spaces. Moreover, dilated congested blood vessels was present in between the muscle bundles (Figures $2 \mathrm{~d} \& 2 \mathrm{e}$ ).

Group IV: revealed an apparent increased thickness of the urothelium compered to group II\&III. However, disrupted lamina propria, inflammatory cell infiltration and dilated congested blood vessels were observed (Figure 3a). There were bundles of smooth muscle, but some of them were still degenerated leaving wide spaces (Figure 3b).

Group V: showed apparently normal urothelium and lamina propria with few inflammatory cell infiltration (Figure 4a). The smooth muscle bundles appeared more or less normal and running in different directions (Figure 4b).

\section{Masson Trichrome Stain}

Group I showed usual distribution of the collagen fibers in the lamina propria and in between the smooth muscle bundle (Figure 5a). Groups II and III revealed intense collagen fibers deposition in the lamina propria and in between muscle bundle (Figures $5 \mathrm{~b} \& 5 \mathrm{c}$ ). Group IV demonstrated moderate deposition of collagen fibers (Figure 5d) while, Group V revealed normal collagen fibers distribution in the lamina propria and in between muscle bundle (Figure 5e)

\section{Immunohistochemical Stains}

\section{1- Nuclear Factor-א B Immunostaining}

Group I showed minimal NF- $\kappa$ B immunoreaction in both the urothelium and the lamina propria (Figure 6a). Groups II and III showed strong NF- $\kappa$ B immunoreaction in both the urothelium and the lamina propria (Figures $6 \mathrm{~b} \& 6 \mathrm{c}$ ). Group IV showed moderate NF-к B immunoreaction in both the urothelium and the lamina propria (Figure 6d), but immunoreaction was weak in group V (Figure 6e).

\section{2- Antiproliferating Cell Nuclear Antigen Immunostaining}

The sections from groups I, II and III showed some PCNA immunopositive nuclei among urothelium 
(Figures 7a \& 7b \& 7c). Group IV revealed moderate PCNA immunopositive nuclear reaction among urothelium (Figure 7d), while, there were many PCNA immunopositive nuclei among urothelium of group $\mathrm{V}$ (Figure 7e).

\section{3- Desmin immunostaining}

Group I showed intense brown immunoreaction of desmin intermediate filaments inside the cytoplasm of the smooth muscle fibers (Figure 8a), while desmin immunoreaction was mild in groups II and III (Figures $8 \mathrm{~b} \& 8 \mathrm{c}$ ). Group IV revealed moderated brown immunoreaction of desmin intermediate filaments (Figure 8d) while in group $\mathrm{V}$, the immunoreaction of desmin intermediate filaments was strong brown (Figure 8e).

\section{Morphometric Results}

Mean area percentage \pm SD of Masson's trichrome, NF- $\kappa$ B, PCNA and desmin immunostaining are presented in (Tables and Histograms 1,2,3 and 4). The mean area percentage of Masson's trichrome staining of collagen fibers and $\mathrm{NF}-\kappa \mathrm{B}$ immunoexpression were significantly increased $(P<0.01)$ in groups II and III compared with group I, while in groups IV and V there was a significant reduction $(P<0.01)$ compared with groups II and III. The mean area percentage of PCNA immunostaining was non significantly increased $(P<0.01)$ in groups II and III compared with group I. Groups IV and V showed significant increase $(P<0.01)$ of PCNA immunostaining compared with groups I\&II and III. Mean area percentage of desmin immunostaining was significantly decreased $(P<0.01)$ in groups II and III in comparison to group I. Groups IV and V showed significant increase of desmin immunostaining $(P<0.01)$ compared with groups II and III.

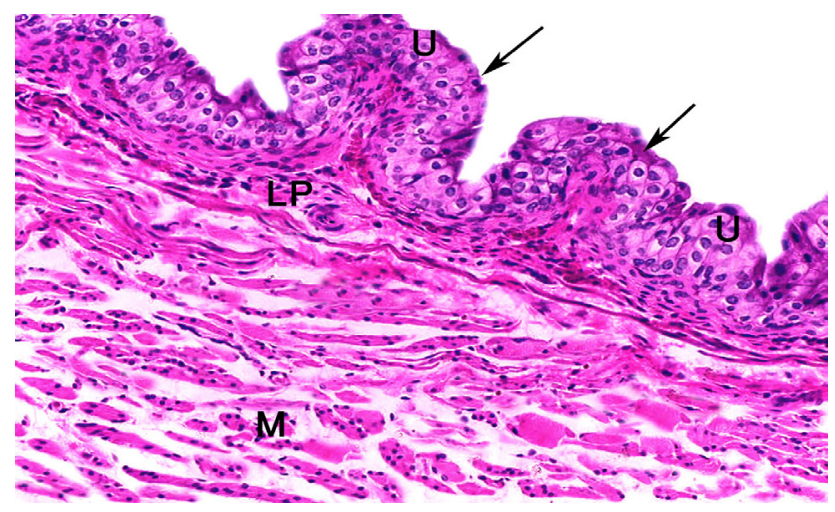

Fig. 1(a): A photomicrograph of a section in the urinary bladder of group I showing highly folded mucosa $(\uparrow)$ lined by transitional urothelium (U) with underlying lamina propria (LP) and smooth muscle bundles (M) $(\mathrm{H} \& \mathrm{E}, \times 400)$.

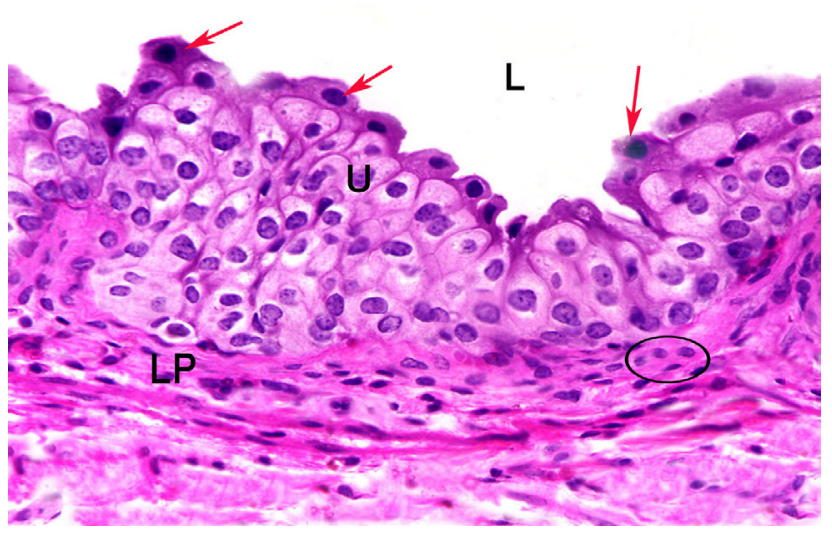

Fig. 1(b): Showing urothelial lining (U) formed of transitional epithelium with superficial umbrella-like cells $(\uparrow)$ bulging into the lumen $(\mathrm{L})$. The underlying lamina propria (LP) is dense collagenous and contains a number of lymphocytes (circle). (H\&E, ×630).

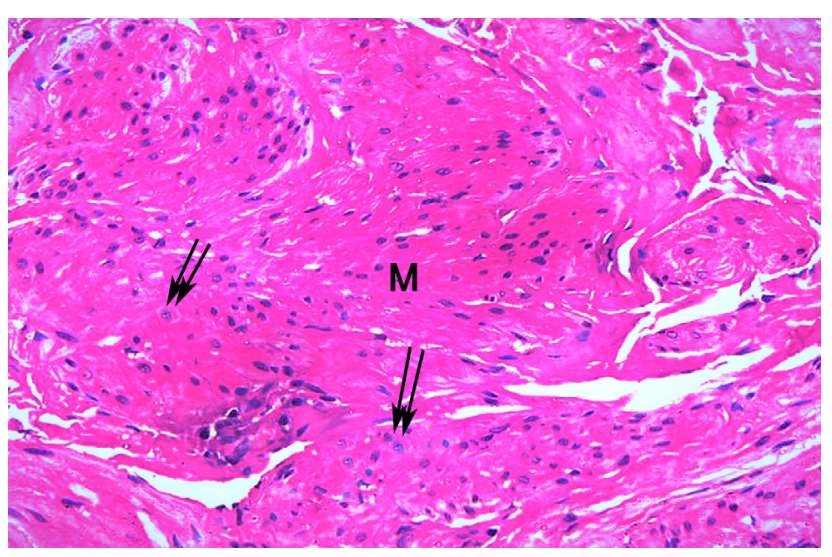

Fig. 1(c): Showing smooth muscle bundles (M) running in different directions. They have central vesicular nuclei $(\uparrow \uparrow)$ and acidophilic cytoplasm $(\mathrm{H} \& \mathrm{E}, \times 630)$.

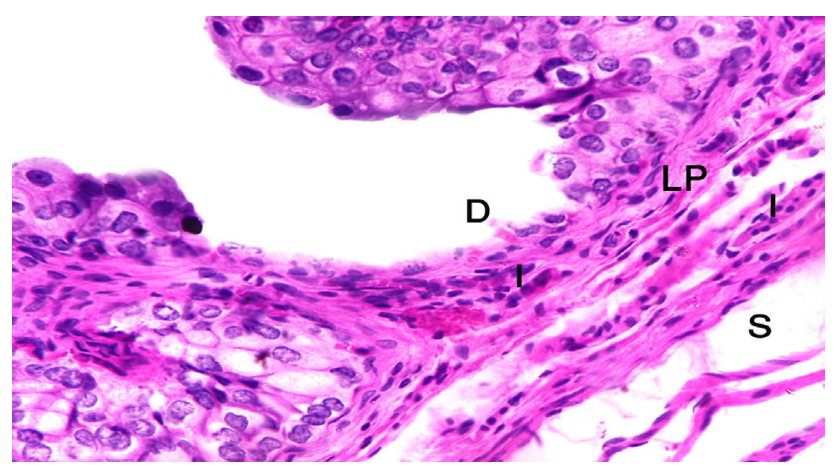

Fig. 2(a): A photomicrograph from group II showing focal area of degeneration and ulceration of transitional epithelium (D). Notice wide spaces (S) and inflammatory cell infiltration (I) in the lamina propria (LP) (H\&E, ×630). 


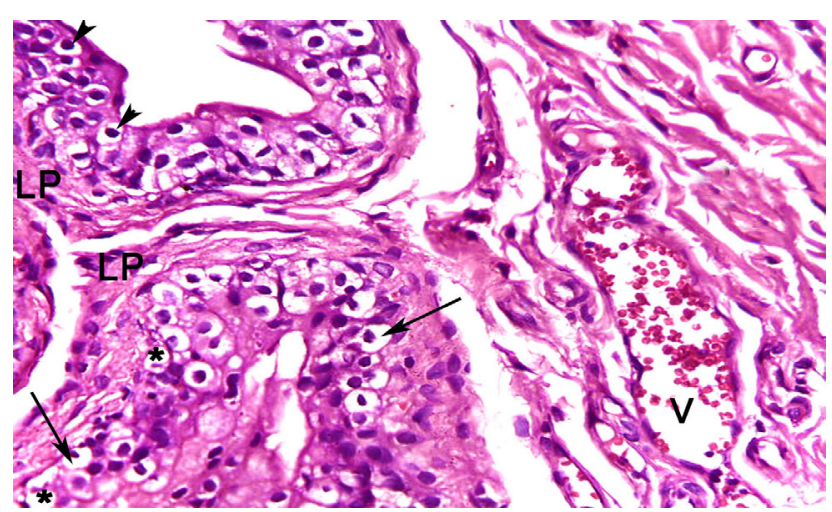

Fig. 2(b): Group II showing vacuolated urothelial cells ( $\uparrow$ ) with darkly stained nuclei ( $\boldsymbol{\Delta}$ ) and karyolitic ones (*). Disrupted lamina propria (LP) containing dilated congested blood vessel $(\mathrm{V})$ is observed $(\mathrm{H} \& \mathrm{E}, \times 630)$.

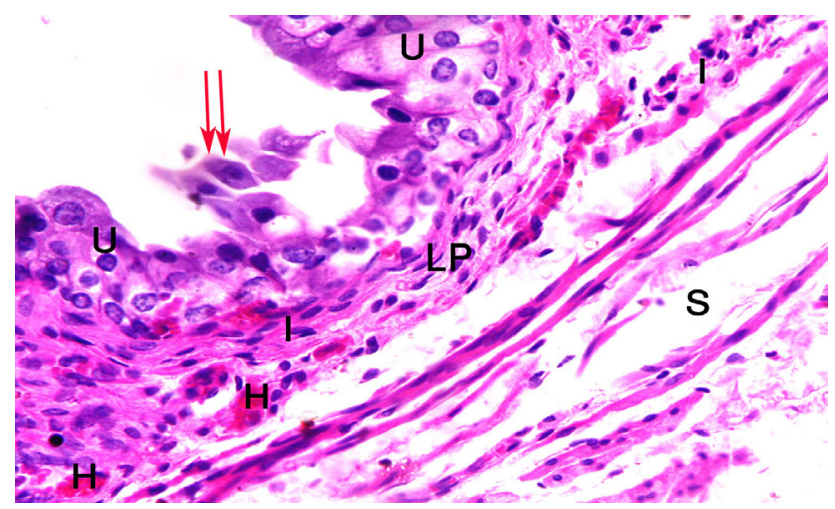

Fig. 2(c): Group III showing an apparently decreased thickness of the urothelium (U) with focal shedding of some cells $(\uparrow \uparrow)$. The lamina propria (LP) shows wide spaces (S), inflammatory cell infiltration (I) and areas of hemorrhage $(\mathrm{H})(\mathrm{H} \& \mathrm{E}, \times 630)$.

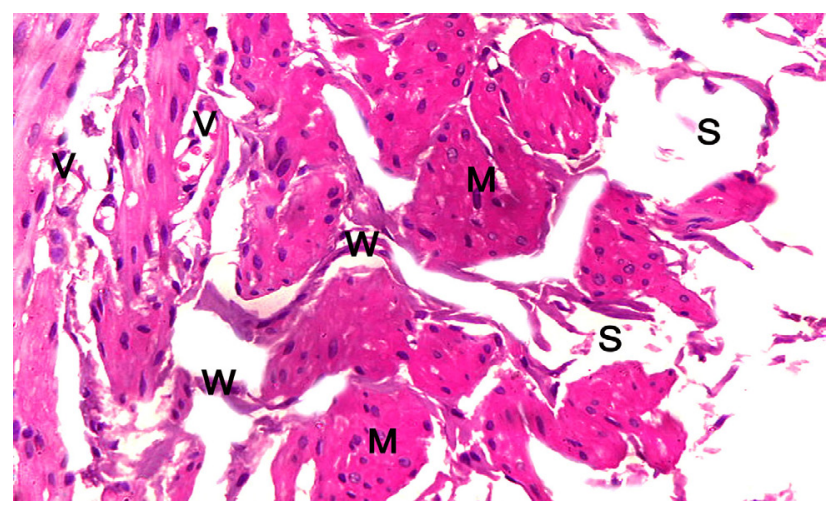

Fig. 2(d): Group II showing bundles of smooth muscle (M). Some of them are degenerated leaving wide spaces (S). Wavy collagen fibers (W) and dilated congested blood vessels (V) are present in between the bundles $(\mathrm{H} \& \mathrm{E}, \times 630)$.

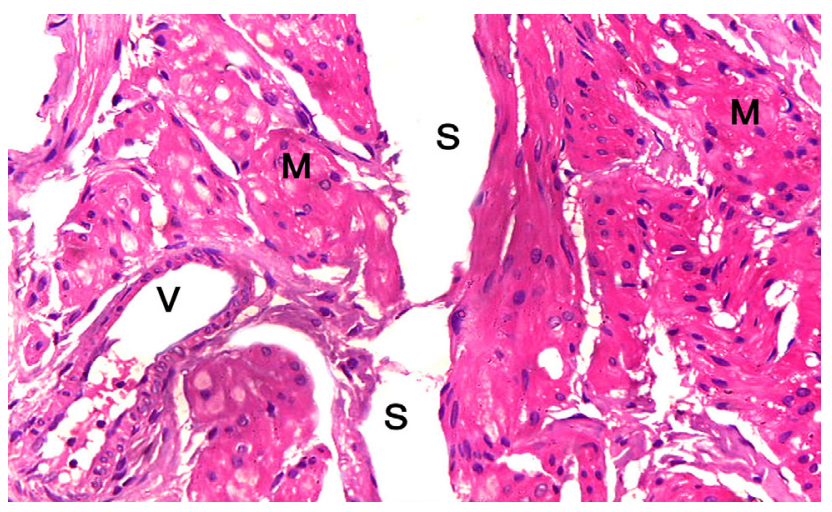

Fig. 2(e): Group III showing degenerated bundles of smooth muscle (M) Note the presence of wide spaces (S) and dilated congested blood vessels (V) in between the muscle bundles (H\&E, × 630).

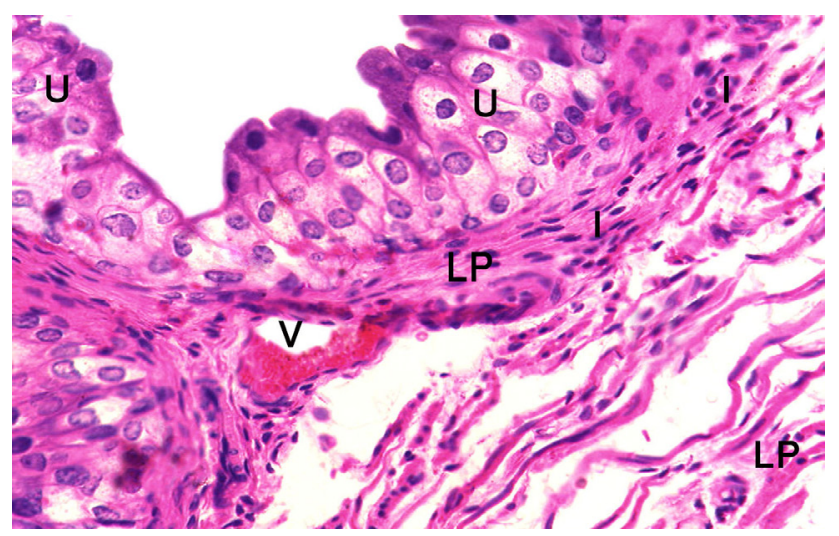

Fig. 3(a): A photomicrograph of a section in the urinary bladder of group IV showing intact urothelium (U). Disrupted lamina propria (LP), inflammatory cell infiltration (I) and dilated congested blood vessels (V) are observed $(\mathrm{H} \& \mathrm{E}, \times 630)$.

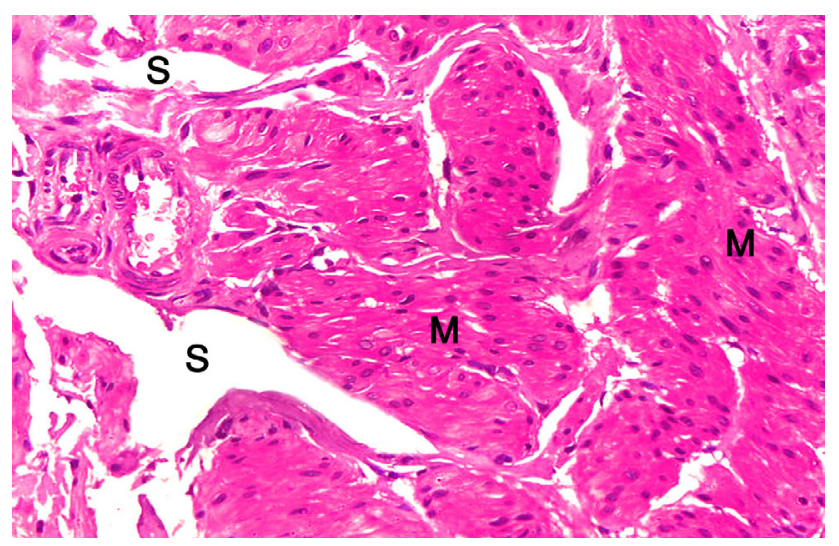

Fig. 3(b): Showing bundles of smooth muscle (M). Some of them are still degenerated leaving wide spaces $(\mathrm{S})(\mathrm{H} \& \mathrm{E}, \times 630)$. 


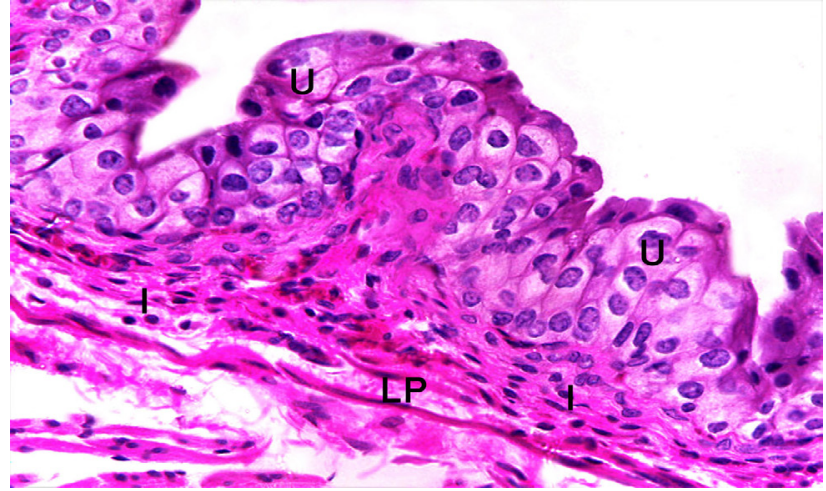

Fig. 4(a): A photomicrograph of a section in the urinary bladder of group $\mathrm{V}$ showing apparently normal urothelium (U) and lamina propria (LP) with few inflammatory cell infiltration (I) $(\mathrm{H} \& \mathrm{E}, \times 630)$.

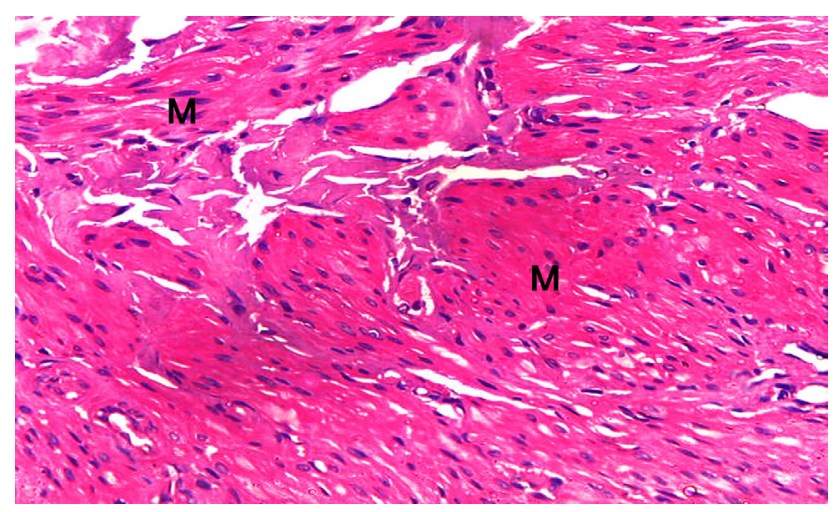

Fig. 4(b): Showing more or less normal appearance of the smooth muscle bundles $(\mathrm{M})$ running in different directions $(\mathrm{H} \& \mathrm{E}, \times 630)$.

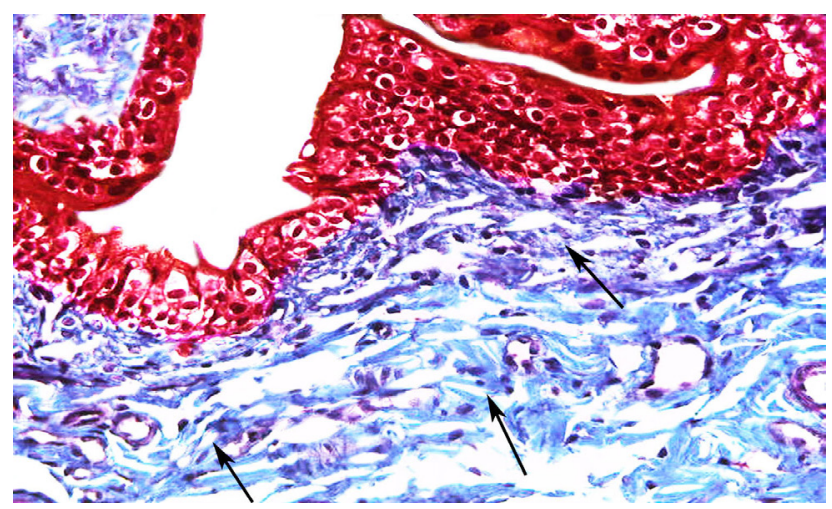

Fig. 5(a): A photomicrograph of a section in the urinary bladder of group I showing normal distribution of the collagen fibers in the lamina propria beneath the epithelium and in between the smooth muscle bundle $(\uparrow)$ (Masson's trichrome $\times 400$ )

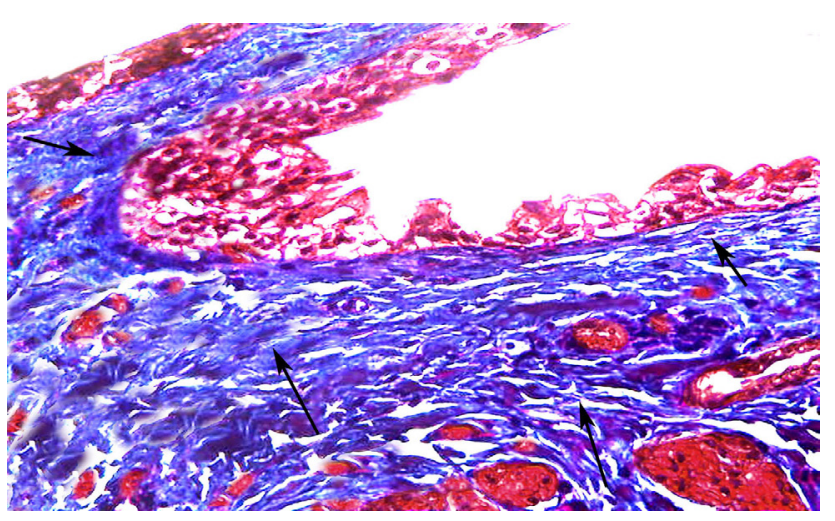

Fig. 5(b): Group II showing intense collagen fibers deposition in the lamina propria and in between muscle bundle $(\uparrow)$ (Masson's trichrome $\times 400)$.

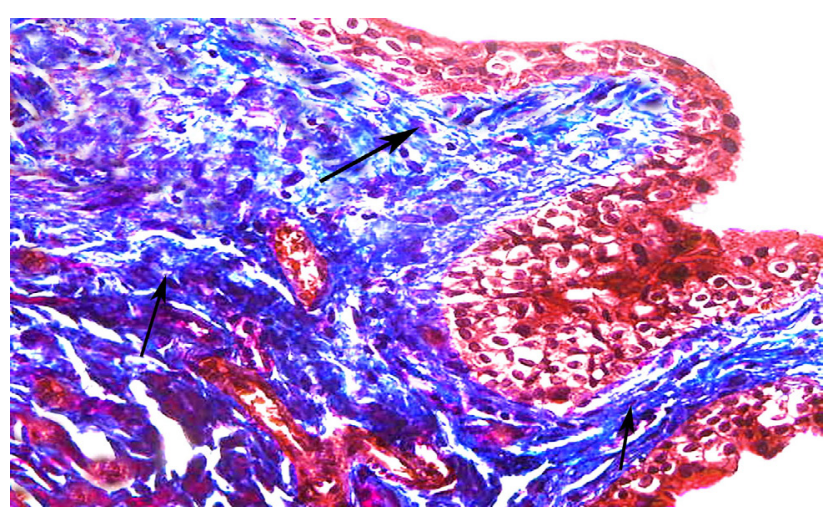

Fig. 5(c): Group III showing dense deposition of collagen fibers in the lamina propria and in between muscle bundle $(\uparrow)$ (Masson's trichrome $\times 400)$.

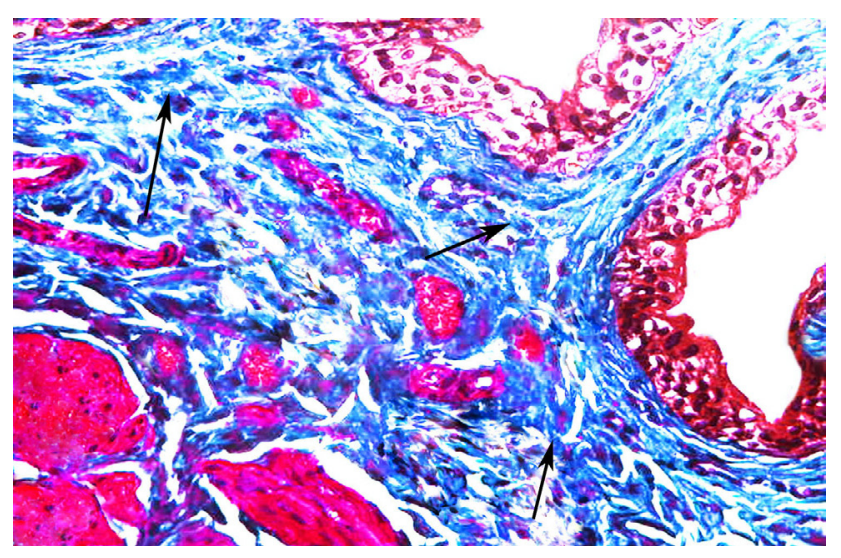

Fig. 5(d): Group IV showing moderate deposition of collagen fibers in the lamina propria and in between muscle bundle $(\uparrow)$ (Masson's trichrome $\times 400)$. 


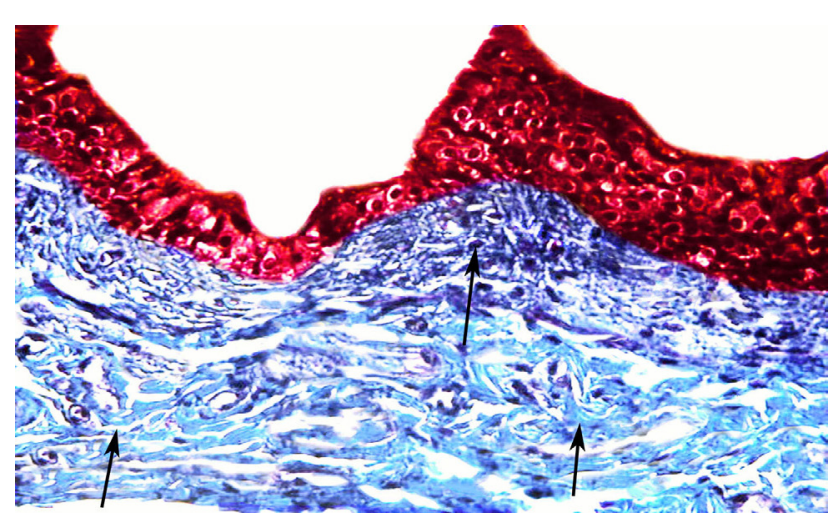

Fig. 5(e): Group V showing deposition of collagen fibers in the lamina propria and in between muscle bundle $(\uparrow)$ (Masson's trichrome $\times 400$ ).

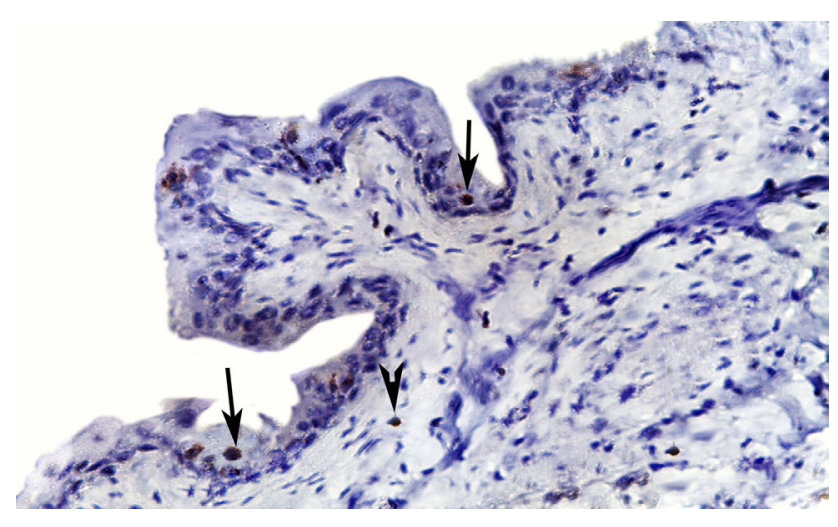

Fig. 6(a): A photomicrograph of a section in the urinary bladder of group I showing minimal NF- $\mathrm{B}$ immunoreaction in the urothelium $(\uparrow)$ and lamina propria $(\boldsymbol{\Delta})$ (Immunostaining for NF- $\kappa \mathrm{B} \times 400$ ).

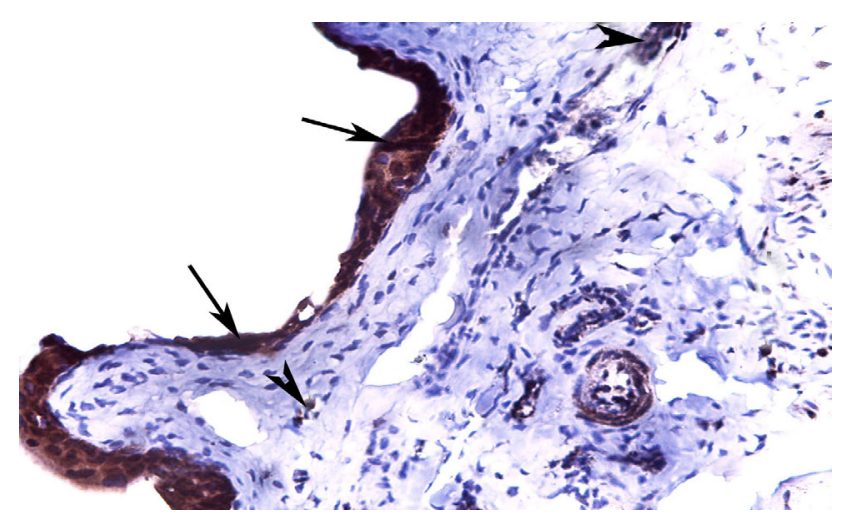

Fig. 6(b): Group II showing strong NF- $\kappa \mathrm{B}$ immunoreaction in the urothelium $(\uparrow)$ and lamina propria $(\boldsymbol{\Delta})$ (Immunostaining for NF- $\kappa$ B $\times 400)$.

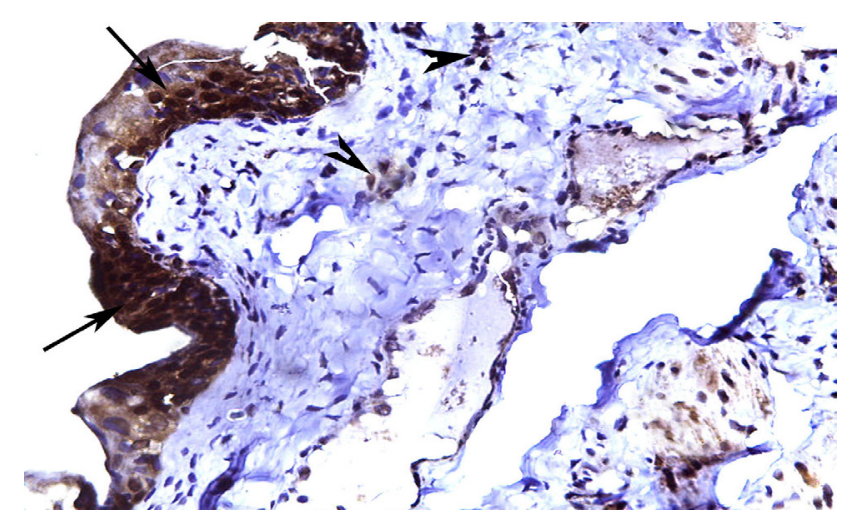

Fig. 6(c): Group III showing intense NF- $\kappa$ B immunoreaction in the urothelium $(\uparrow$ ) and lamina propria $(\boldsymbol{\Delta})$ (Immunostaining for NF- $\kappa$ B $\times 400)$.

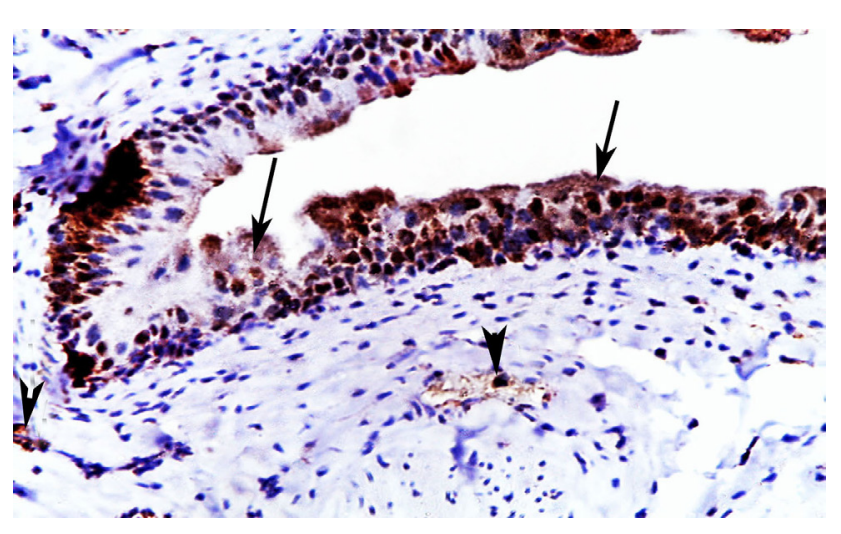

Fig. 6(d): Group IV showing moderate NF- $\kappa$ B immunoreaction in the urothelium $(\uparrow)$ and lamina $\operatorname{propria}(\boldsymbol{\Delta})$ (Immunostaining for $\mathrm{NF}-\kappa \mathrm{B}$ $\times 400)$.

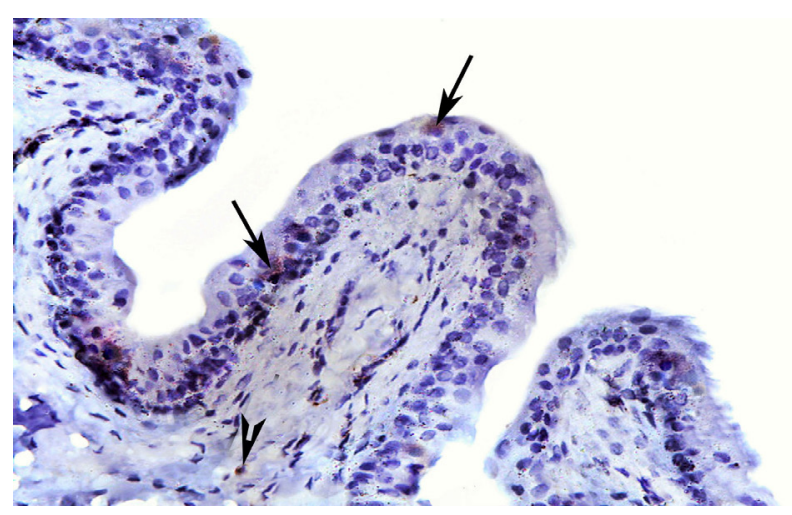

Fig. 6(e): Group V showing weak NF- $\mathrm{B}$ immunoreaction in both the urothelium $(\uparrow)$ and the lamina propria $(\boldsymbol{\Delta})$ (Immunostaining for NF- $\kappa$ $\mathrm{B} \times 400)$. 


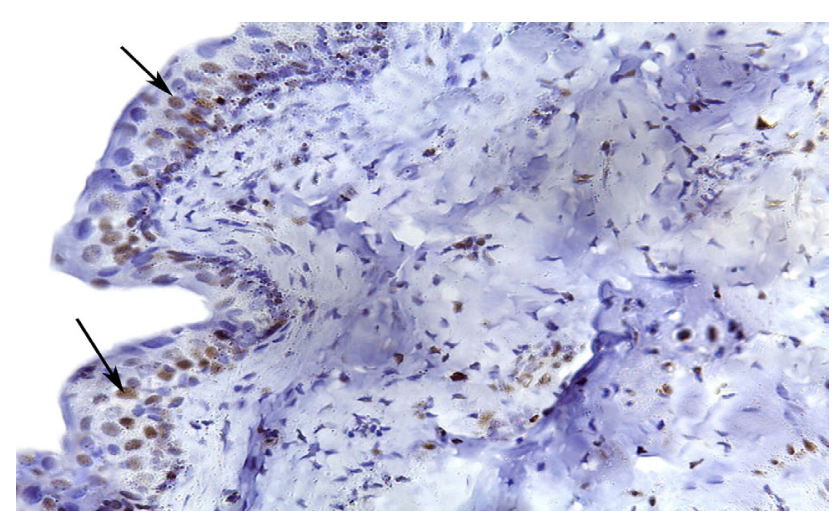

Fig. 7(a): A photomicrograph of a section in the urinary bladder of group I showing some PCNA immunopositive nuclei $(\uparrow)$ among urothelium (Immunostaining for PCNA $\times 400$ ).

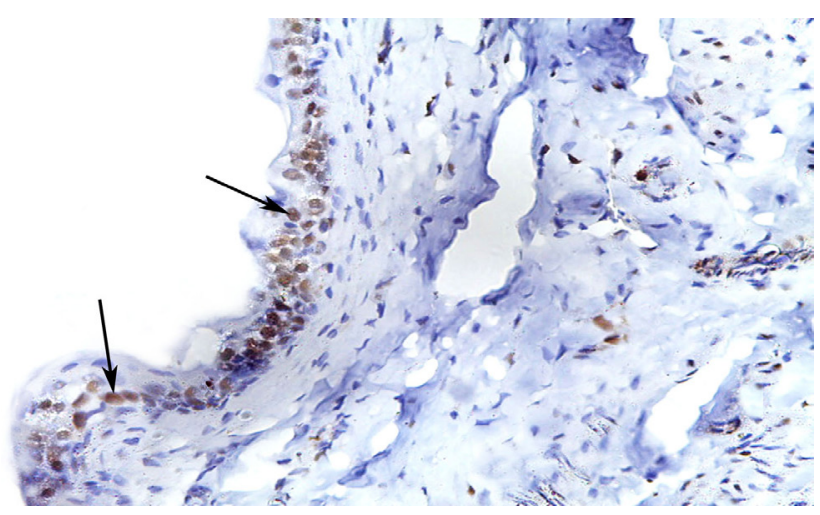

Fig. 7(b): Group II showing some PCNA immunopositive nuclei ( $\uparrow$ ) among urothelium (Immunostaining for PCNA $\times 400$ ).

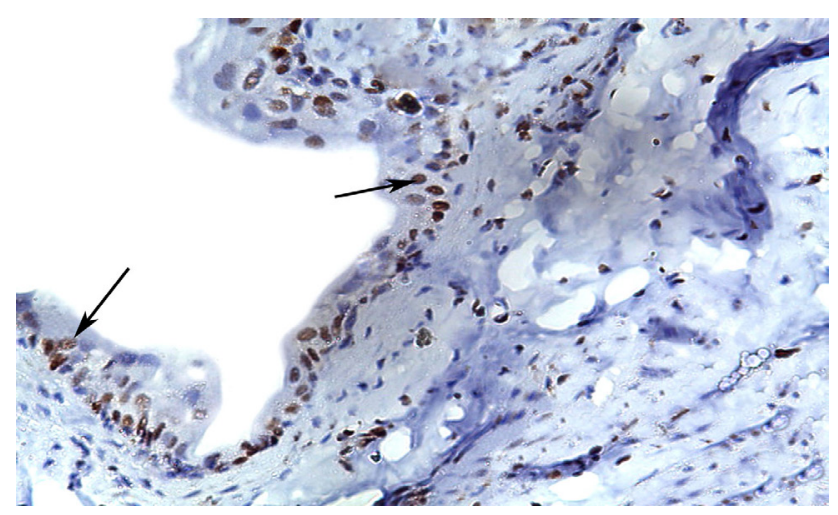

Fig. 7(c): Group III showing some PCNA immunopositive nuclei ( $\uparrow$ ) among urothelium (Immunostaining for PCNA $\times 400$ ).

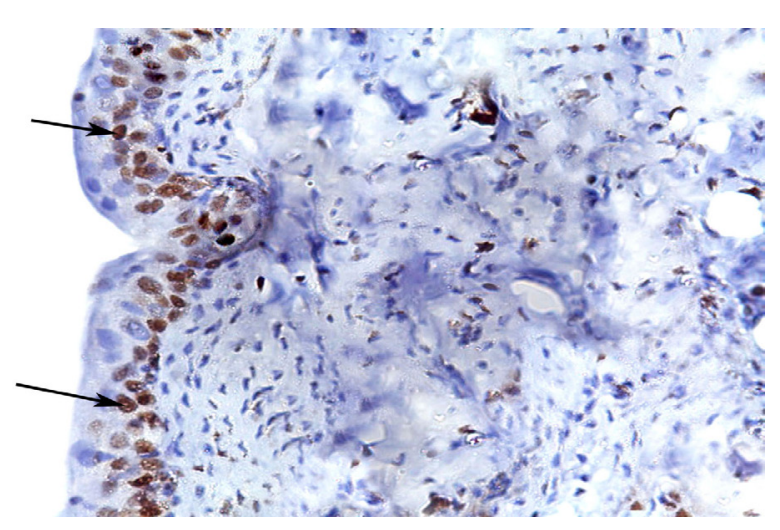

Fig. 7(d): Group IV showing many PCNA immunopositive nuclei $(\uparrow)$ among urothelium (Immunostaining for PCNA $\times 400$ ).

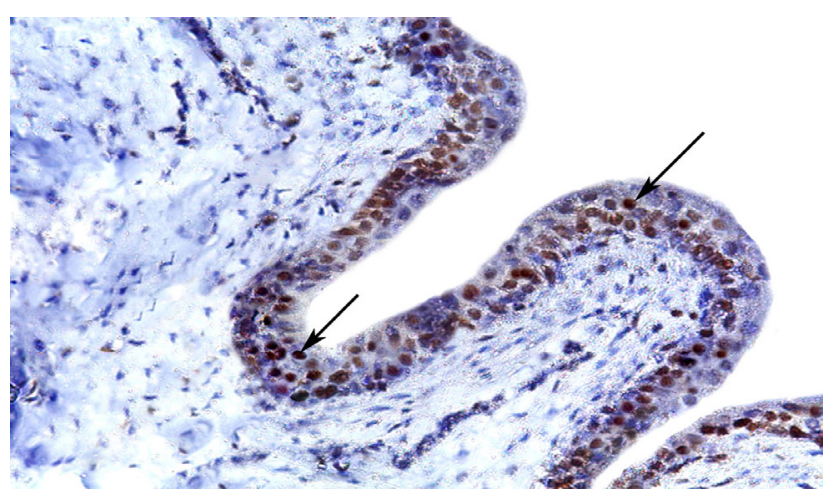

Fig. 7(e): Group V showing many PCNA immunopositive nuclei ( $\uparrow)$ among urothelium (Immunostaining for PCNA $\times 400$ ).

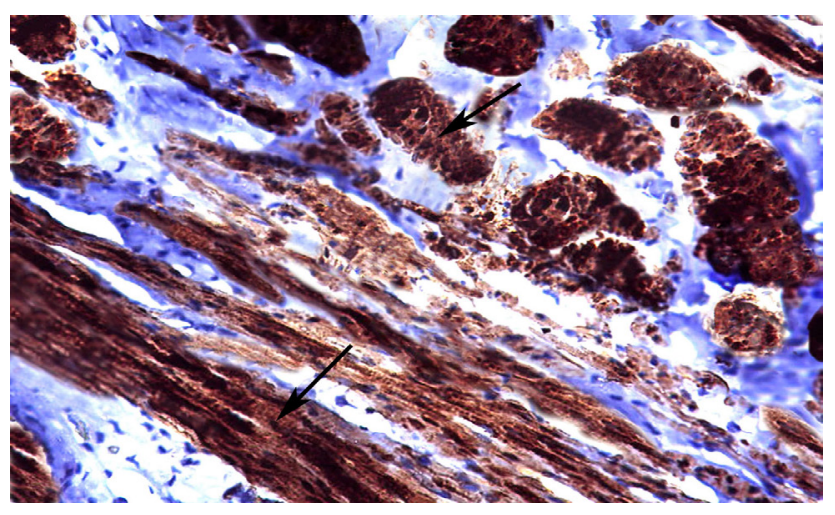

Fig. 8(a): A photomicrograph of a section in the urinary bladder of group I showing intense brown immunoreaction of desmin intermediate filaments $(\uparrow)$ inside the cytoplasm of the smooth muscle fibers (Immunostaining for desmin $\times 400)$. 


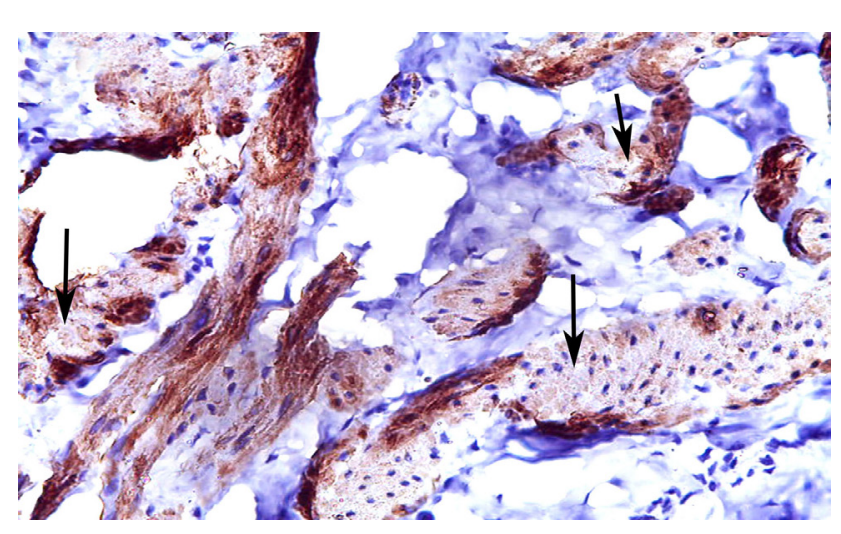

Fig. 8(b): Group II showing mild brown immunoreaction of desmin intermediate filaments $(\uparrow)$ (Immunostaining for desmin $\times 400)$.

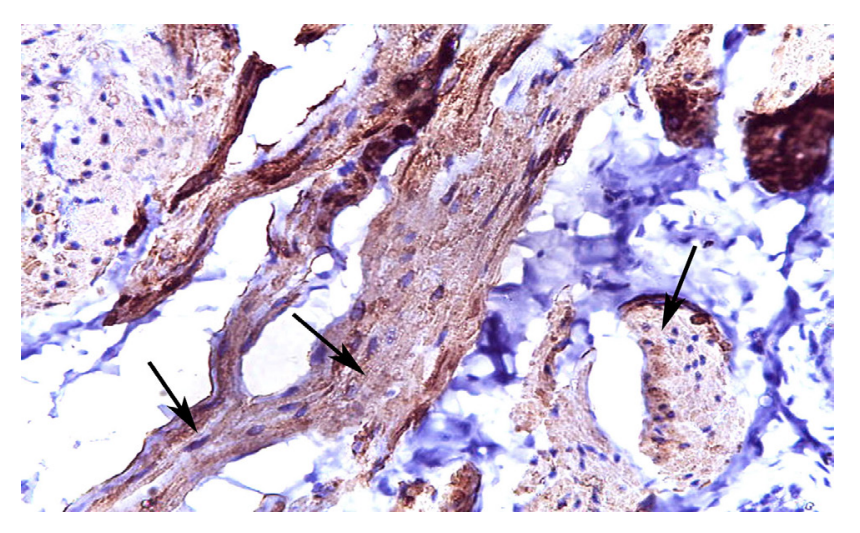

Fig. 8(c): Group III showing mild brown immunoreaction of desmin intermediate filaments $(\uparrow)$ (Immunostaining for desmin $\times 400)$.

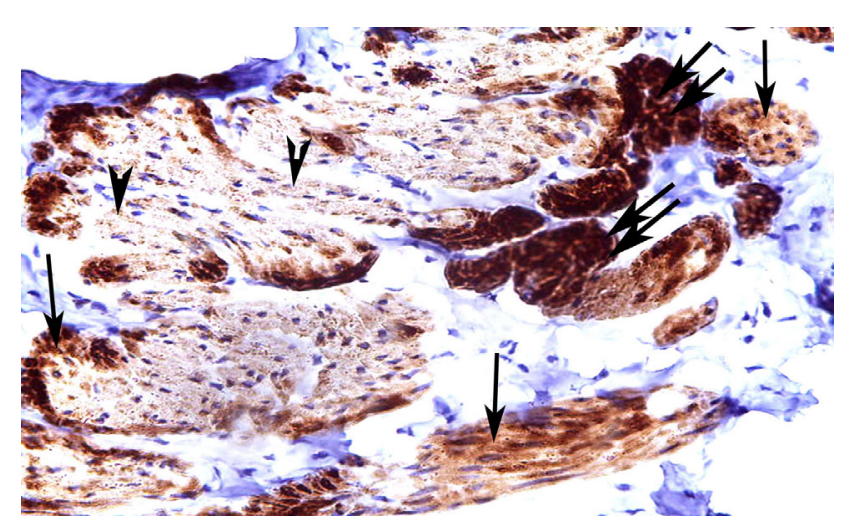

Fig. 8(d): Group IV showing moderated brown immunoreaction in some of desmin intermediate filaments $(\uparrow)$ and intense in others ( $\uparrow)$. Also, some desmin filaments show weak reaction $(\mathbf{A})$. (Immunostaining for desmin $\times 400)$.

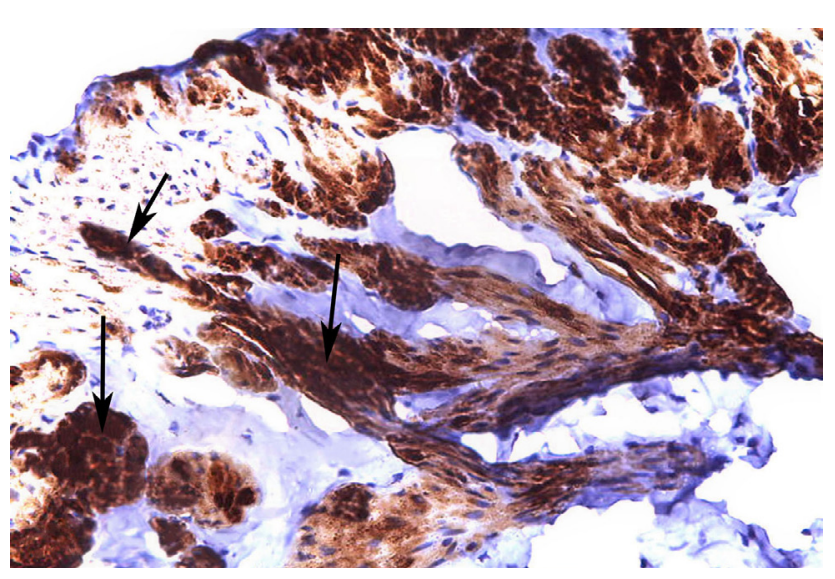

Fig. 8(e): Group V showing strong brown immunoreaction in the most of desmin intermediate filaments $(\uparrow)$ (Immunostaining for desmin $\times 400$ ).

Table 1: Comparison of collagen fibers deposition in all groups

\begin{tabular}{cccccc}
\hline & Group I & Group II & Group III & Group IV & Group V \\
\hline \multicolumn{1}{c}{ Mean } & $12.87 \%$ & $23.56 \%$ & 22.91 & $17.09 \%$ & $14.76 \%$ \\
SD & 0.7000 & 1.1334 & 0.9961 & 0.8871 & 0.7568 \\
$\begin{array}{l}\text { Significance } \\
\text { at } P<0.01\end{array}$ & $2,3,4,5$ & $1,4,5$ & $1,4,5$ & $1,2,3,5$ & $1,2,3,4$ \\
\hline $\begin{array}{l}\text { 1=sig. with group I } \\
\text { 4=sig. with group IV }\end{array}$ & 2=sig. with group II & $\begin{array}{r}\text { 3=sig. with group III } \\
\text { 5=sig. with group V. }\end{array}$
\end{tabular}

Table 2: Comparison of NF-kB immunostaining in all groups

\begin{tabular}{cccccc}
\hline & Group I & Group II & Group III & Group IV & Group V \\
\hline Mean & $1.19 \%$ & $5.61 \%$ & 5.96 & $3.47 \%$ & $1.65 \%$ \\
SD & 0.4075 & 0.6984 & 0.4059 & 0.6803 & 0.4002 \\
$\begin{array}{c}\text { Significance } \\
\text { at } P<0.01\end{array}$ & $2,3,4$ & $1,4,5$ & $1,4,5$ & $1,2,3,5$ & $2,3,4$ \\
\hline
\end{tabular}

1=sig. with group I $2=$ sig. with group II $3=$ sig. with group III $4=$ sig. with group IV $5=$ sig. with group V.

Table 3: Comparison of PCNA immunostaining in all groups

\begin{tabular}{cccccc}
\hline & Group I & Group II & Group III & Group IV & Group V \\
\hline Mean & $0.76 \%$ & $0.79 \%$ & 0.70 & $1.79 \%$ & $2.80 \%$ \\
SD & 0.0308 & 0.02312 & 0.0595 & 0.1455 & 0.1095 \\
$\begin{array}{c}\text { Significance } \\
\text { at } P<0.01\end{array}$ & 4,5 & 4,5 & 4,5 & $1,2,3,5$ & $1,2,3,4$ \\
\hline
\end{tabular}

1=sig. with group I $2=$ sig. with group II $3=$ sig. with group III $4=$ sig. with group IV $5=$ sig. with group $\mathrm{V}$. 
Table 4: Comparison of desmin immunostaining in all groups

\begin{tabular}{cccccc}
\hline & Group I & Group II & Group III & Group IV & Group V \\
\hline Mean & $26.66 \%$ & $6.94 \%$ & $7.87 \%$ & $19.25 \%$ & $27.64 \%$ \\
SD & 1.1720 & 1.2928 & 1.6892 & 1.5084 & 1.3477 \\
$\begin{array}{l}\text { Significance } \\
\text { at } P<0.01\end{array}$ & $2,3,4$ & $1,4,5$ & $1,4,5$ & $1,2,3,5$ & $2,3,4$ \\
\hline $\begin{array}{l}\text { 1=sig. with group I } \\
\text { 4=sig. with group IV }\end{array}$ & 2=sig. with group II & 3=sig. with group III \\
4 & & & 5=sig. with group V
\end{tabular}

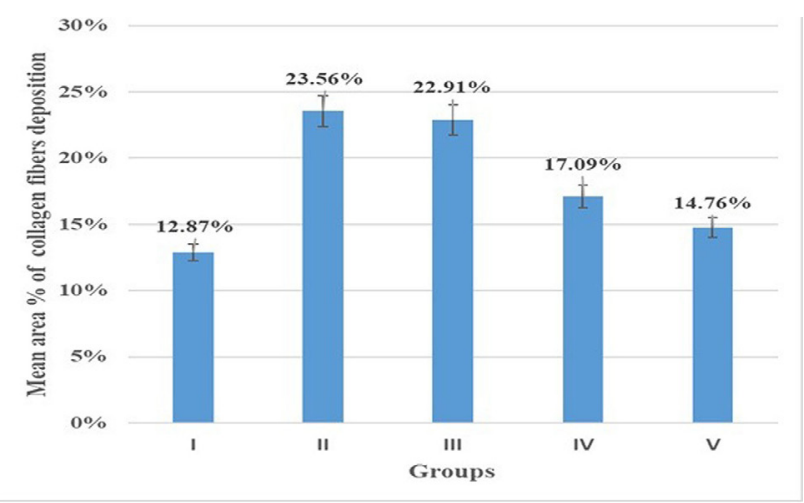

Histogram 1: Showing the mean area \% of collagen fibers deposition in all groups.

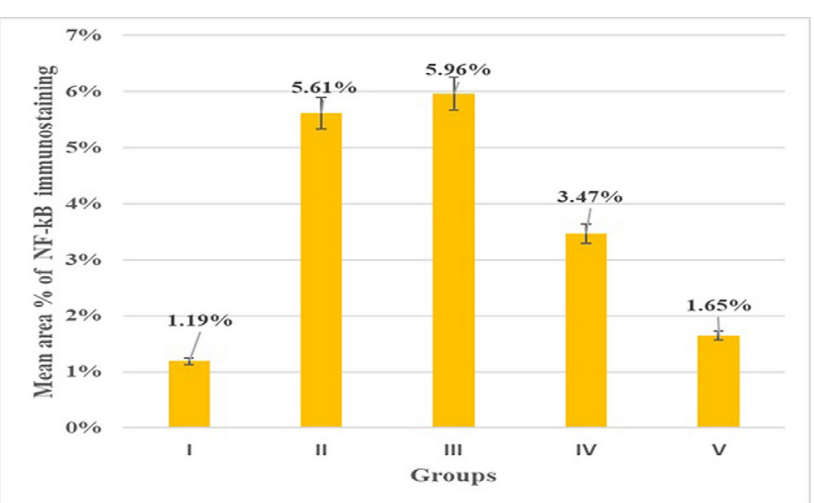

Histogram 2: Showing the mean area \% of NF-kB immunostaining in all groups.

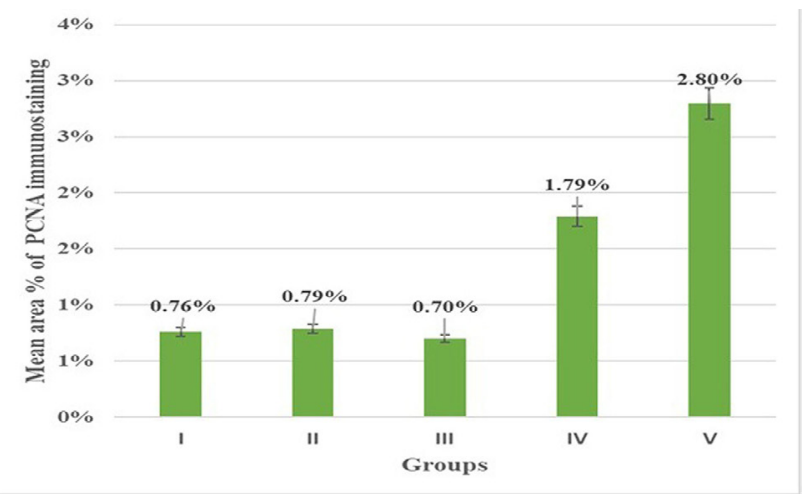

Histogram 3: Showing the mean area \% of PCNA immunostaining in all groups.

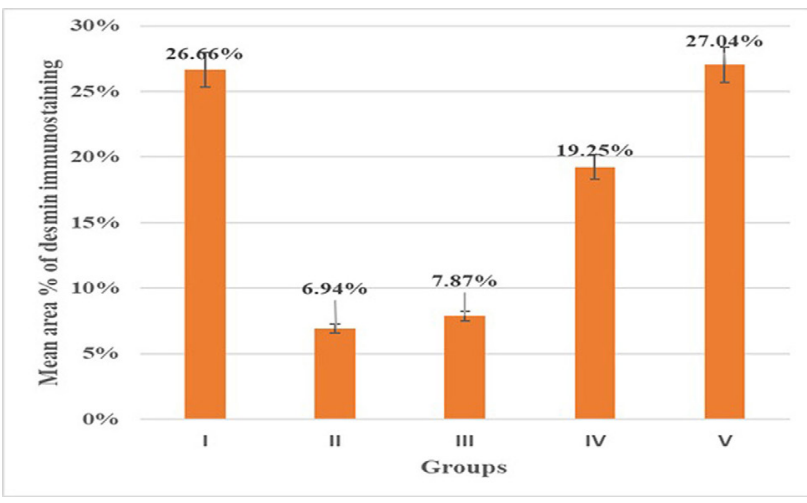

Histogram 4: Showing the mean area \% of desmin immunostaining in all groups

\section{DISCUSSION}

Ketamine- induced cystitis is a popular disease associated with ketamine administration ${ }^{[22]}$. Its clinical manifestations include various lower urinary tract symptoms which are identical with that of interstitial cystitis/ bladder pain syndrome ${ }^{[18]}$.

The light and immunohistochemical examination of sections from groups II \& III showed the same results. They revealed several changes such as focal areas of degeneration and ulceration with apparently decreased thickness of the transitional epithelium. The lamina propria showed inflammatory cell infiltration and dilated congested blood vessels. The smooth muscle bundles were degenerated leaving wide spaces. There was a significant $(P<0.01)$ increase of collagen fibers deposition and NF$\kappa \mathrm{B}$ immunoreaction, but non-significant increase of PCNA immunopositive nuclear reaction among urothelium. Desmin immunoreaction was significantly decreased $(P<0.01)$, compared to group I.

Our results were in accordance with previous studies ${ }^{[6,7,27,28]}$ who reported that ketamine treatment was associated with a significant reduction in the urothelial thickness, hemorrhage, inflammatory cells infiltration, and interstitial fibrosis of bladder. Other investigators ${ }^{[5,29]}$ have clarified that, in animal models exposed to ketamine, the permeability of the urothelium was increased, which could explain the damage, vacuolization of cells, and widening of the intercellular spaces beyond the superficial layer of urothelium.

The inflammatory mononuclear cell infiltration could be explained by increasing many cytokines as tumor necrosis factor (TNF- $\alpha$ ), interleukin (IL-6) and inducible nitric oxide synthase (iNOS) after ketamine administration which latter on stimulating apoptosis and fibrosis ${ }^{[4,5,30]}$.

Nuclear factor- $\kappa$ B is a member of the protein family which exists in the cytoplasm as an inactive complex bound to inhibitory proteins. Activation of NF- $\kappa$ B with KIC induces various proinflammatory cascade, as cytokines (TNF- $\alpha$, IL-1, IL-6, IL-8, and IL-12), chemokines, and thus plays important roles in the immune and inflammation processes $^{[31-34]}$. The current results agreed with a study ${ }^{[35]}$ 
done previously and reported that the significant increase of NF- $\kappa$ B in both the urothelium and the lamina propria induce bladder toxicity and has vital role in the pathogenesis of cystitis in rats.

Proliferating cell nuclear antigen (PCNA) is a nonhistone nuclear protein that used as a standard marker for cellular proliferation activity ${ }^{[36]}$. Our findings were coincided with previous researches ${ }^{[12,23,37]}$, who stated that urothelium is a very stable type of tissue and has a slow proliferative activity. However, after exposure to an injury, which causes loss of superficial cells, tight junctions are damaged, and the proliferative activity of the basal urothelial cells are increased rapidly

Desmin is the predominant intermediate filament protein in the visceral smooth muscle ${ }^{[38]}$. The current work showed marked degeneration of the smooth muscle bundles in the sections of groups II\&III. Our results were identical with the findings of prior researches ${ }^{[28,29,39,40]}$ who stated that ketamine can cause damage in the mucosal, submucosal, and muscular layers of the bladder Also, they suggested that the degeneration and wide spaces between the muscle bundles, are a result of the dilatation in the lymphatic vessels, which are confined mainly in the muscle layer.

Several reporters ${ }^{[4,5,41,42]}$ explained that the most possible mechanism of KIC is mediated through multifactorial process such as metabolization of ketamine by cytochrome p450 in the liver into two principal metabolites (norketamine and di-hydronorketamine), which are excreted primarily in urine and to a much lesser extent in the feces. Ketamine and its metabolites accumulate in the urine and induce disruption of the urothelial barrier, bladder irritation and damage. Moreover, ketamine increases the oxidative stress products (ROS), and reactive nitrogen species (RNS) which induces oxidative stress, and in turn triggers cellular changes such as DNA damage, apoptosis, cytokine production and finally inflammation ${ }^{[7,22,41,42]}$.

Group IV of current research revealed some improvement of the histological changes noticed in groups II\&III. Moreover, there was a significant $(P<0.01)$ decrease in the collagen fibers deposition. Proliferating cell nuclear antigen immunopositive nuclei and Desmin immunoreaction were significantly $(P<0.01)$ increased, while, NF- $\kappa$ B immunoreaction was significantly decreased compared to group I.

Intravesical administration of PRP was chosen in our study because it can provide more intensive use of the PRP in the bladder and reduce its systemic adverse effects ${ }^{[20]}$.

Our observation confirms the findings of other studies ${ }^{[1,43]}$ suggesting that intravesical instillation of PRP enhances healing of bladder mucosal wound, and repair the defective urothelium. Though direct contact of PRP with the damaged urothelium can initiate cell proliferations above basement membrane and thus protect the urothelium.
Other researches ${ }^{[1,12,44]}$ attributed the ability of PRP to accelerate the epithelial cell regeneration to the biological effects of many growth factors and different cytokines as platelet derived growth factor, vascular endothelial growth factor and transforming growth factor of platelets. These growth factor leads to cell proliferation of epithelial cells, promote tissue angiogenesis, increase blood flow, and improve oxygenation in the site of injury. Proliferating cell nuclear antigen improve inflammation through increasing the intracellular expression of the anti-inflammatory mediators (IL-4, IL-10, and IL-13) and inhibition of NF$\mathrm{kB}^{[9,45,46]}$. Furthermore, the macrophages and neutrophils recruited by the platelets may also have vital actions in elimination of the inflammation and infection ${ }^{[1]}$.

Different researches ${ }^{[9,11,13,44]}$ found that PRP has an antifibrotic effect as it contains antifibrotic molecules, growth factors, and serum amyloid protein which could ameliorate the fibrosis. Additionally, PRP treatment increases muscle regeneration by stimulating myogenesis ${ }^{[47,48]}$. Also, it had antiapoptotic effect by downregulating the expression of apoptotic genes as DAPK1 and BIM mRNA and inhibiting p53, Bax, and caspase-3 levels ${ }^{[9]}$.

Group V of the present study showed a marked improvement confirmed by the histological, immunohistochemical, and morphometric results.

Preservation of the histological structures with HA were an identity with previous researchers ${ }^{[17,19]}$, who stated that HA facilitates the process of wound healing, reepithelization and hasten the tissue regeneration rate.

Some researchers ${ }^{[17,19,21]}$ mentioned that HA has an immune-modulatory effect through reduction of secretion of the proinflammatory cytokines such as TNF- $\alpha$, IL-1, and IL-6 and finally lead to limit inflammation. Also, previous authors ${ }^{[19]}$ concluded in their studies on urinary bladder that HA preserved antioxidant enzymes, eventually lead to accelerate epithelial healing of the bladder mucosa and inhibits fibrosis.

Collectively, HA therapeutic effects on urothelial cells could be caused by a combination of multiple mechanisms, such as, coating of the uroepithelium and antioxidant activity against cellular oxidative stress. Also, anti-inflammatory, antiapoptotic, anti-fibrotic and antiproliferation effects were the other different mechanisms ${ }^{[17,19,49]}$.

\section{CONCLUSION}

The intravesical injection of PRP and HA provide a positive impact on the treatment of Ketamine-induced cystitis. Hyaluronic acid therapy is a more efficient mean as it provides a better improvement in healing of urothelium and promotes more rapid tissue regeneration. However, further clinical studies on human populations for longer periods are still required to emphasize the results obtained from animal studies. 


\section{CONFLICTS OF INTEREST}

There are no conflicts of interest.

\section{REFERENCES}

1. Ke QS, Jhang JF, Lin TY, Ho HC, Jiang YH, Hsu YH et al. Therapeutic potential of intravesical injections of platelet rich plasma in the treatment of lower urinary tract disorders due to regenerative deficiency. Tzu. Chi. Med. J. 2019;31;(3):135-43.

2. Mahal A, Lin NY, Dobberfuhl A, Estes J, Comiter CV. Peroxisome proliferator-activated receptor gamma agonist as a novel treatment for interstitial cystitis: A rat model. Investig. Clin. Urol. 2018;59:257-262.

3. Qi L, Liu JY, Zhu YL, Liu W et al. Toxic effects of ketamine on reproductive system via disrupting hypothalamic-pituitary-testicular axis. European Review for Medical and Pharmacological Sciences. 2017;21:1967-1973.

4. $\mathrm{Wu} \mathrm{ZG}$, Chen $\mathrm{F}, \mathrm{Wu} \mathrm{H}$, Chen JX et al. Urinary metabonomics of rats with ketamine-induced cystitis using GC-MS spectroscopy. Int. J. Clin. Exp. Pathol. 2018;11;(2):558-567.

5. Bureau M, Pelletier J, Rousseau A, Bernard G et al. Demonstration of the direct impact of ketamine on urothelium using a tissue engineered bladder model. Can Urol. Assoc. J. 2015;9;(9-10):E613-617.

6. Lee YL, Lin KL, Chuang SM, Lee YC et al., Elucidating mechanisms of bladder repair after hyaluronan instillation in ketamine-induced ulcerative cystitis in animal model. Am. J. Pathol. 2017;187:1945-e1959.

7. Lee SW, Ryu CM, Shin JH, Choi D et al. The Therapeutic effect of human embryonic stem cellderived multipotent mesenchymal stem cells on chemical-induced cystitis in rats. Int. Neurourol. J. 2018;22;(Suppl 1):S34-45.

8. Tsai YC, Kuo HC. Ketamine cystitis: Its urological impact and management. Urological Science 2015;26:153-157.

9. Salem N, Helmi N, and Assaf N. Reno protective effect of platelet-rich plasma on cisplatin-induced nephrotoxicity in rats. Oxidative Medicine and Cellular Longevity 2018;(2018):1- 10.

10. Ahmed SM, Mahmoud AA, Hassen EZ, Kader RRA. Light and electron microscope study on the effect of platelet-rich plasma in induced renal ischemiareperfusion injury in the renal cortex of adult male albino rats. J. Biochem. Cell Biol.2018;1;(2):1-8.

11. El-Mahalaway AM \& El-Azab NE. Impacts of resveratrol versus platelet-rich plasma for treatment of experimentally lithium-induced thyroid follicular cell toxicity in rats. A histological and immunohistochemical study. Ultrastructural Pathology 2019;43;(1):80-93.
12. Mansy AE, El-Azab NE and El-Mahalaway AM. Histological and immunohistochemical study of the potential healing effects of glucosamine and platelets rich plasma on experimentally induced oral mucositis in adult male rats. Journal of Histology \& Histopathology 2017;4(12):1-8.

13. Salem N, Hamza A, Alnahdi H, Ayaz N. Biochemical and molecular mechanisms of platelet-rich plasma in ameliorating liver fibrosis induced by dimethyl nitrosurea. Cell Physiol. Biochem. 2018;47: 2331-2339.

14. Segari WAO ,Radwan DAR, Abd El Hamid MA. The effect of adding hyaluronic acid to calcium phosphate on periapical tissue healing following per radicular surgery in dogs. Tanta Dental Journal 2014;11: 122-129.

15. Ni Y, Zhao S, YinX, Wang $\mathrm{H}$ et al. Intravesicular administration of sodium hyaluronate ameliorates the inflammation and cell proliferation of cystitis cystica et glandularis involving interleukin-6/ JAK2/Stat3 signaling pathway. Scientific Reports 2017;7;(15892):1-13.

16. Gupta RC, Lall R, Srivastava A and Sinha A. Hyaluronic Acid: Molecular Mechanisms and Therapeutic Trajectory. Front. Vet. Sci.2019; 6;(192):1-24.

17. Fawzy SA, Ahmed NA, Elshafie MDE, Radwan $\mathrm{SH}$.Effect of curcumin versus hyaluronic acid on glucocorticoid induced skin atrophy and subsequent skin abrasions in rats. Egyptian journal of histology 2019;42;(1):35-50.

18. Meng E, Tsao CW, Tang SH, Wu ST et al. Intravesical hyaluronic acid treatment for ketamine-associated cystitis: Preliminary results. Urological Science 2015;26:176-179.

19. Yıldız N, Alpay H, Tuğtepe H, Özdemir Kumral ZN, Akakın D, İlki A, Şener G, Ç Yeğen B. Intravesical hyaluronic acid treatment improves bacterial cystitis and reduces cystitis-induced hypercontractility in rats. Int J Urol. 2015; 22(6):598-603. doi: 10.1111/ iju.12752. Epub 2015 Mar 25. PMID: 25808602

20. Sahiner IF, Soylu H, Ates E, Acar N, Ustunel I, Danisman A. Impact of intravesical hyaluronic acid treatment on bladder inflammation in interstitial cystitis rat model. Int Braz J Urol. 2018;44(5):10141022. doi:10.1590/S1677-5538.IBJU.2017.0713

21. Hsiao MY, Lin AC, Liao WH, Wang TG et al . Drugloaded hyaluronic acid hydrogel as a sustained-release regimen with dual effects in early intervention of tendinopathy. Scientific Reports 2019;9;(4784):1-9.

22. Li M, Yang K, Wang X, XuX, Zhu L, Wang H. Mast cells infiltration and decreased E-cadherin expression in ketamine-induced cystitis. Toxicology Reports 2015;2:205-209.

23. Dönmez MI, İnci K, Zeybek ND, Doğan HS, Ergen A: The Early histological effects of intravesical 
instillation of platelet-rich plasma in cystitis models. Int. Neurourol. J. 2016;20:188-196.

24. El-Tahawy NF, Rifaai RA, Saber EA, Saied SR, Ibrahim RA. Effect of platelet rich plasma (prp) injection on the endocrine pancreas of the experimentally induced diabetes in male albino rats: A histological and immunohistochemical study. J Diabetes Metab. 2017;8;(730):1-9.

25. Bancroft JD and Layton C. The hematoxylin and eo $\neg$ sin, connective mesenchymal tissues with their stains In: Suvarna SK, Layton C and Bancroft JD, editors. Bancroft's Theory and practice of histological techniques. 7th edition. Churchill Livingstone: Philadelphia. 2013:173-212\& 215-238

26. Jackson $P$, Blythe D. Immunohistochemical techniques [chapter 8]. In: Suvarna SK, Layton C, Bancroft JD, editors. Theory and practice of histological techniques. 7th ed. Philadelphia: Churchill Livingstone of Elsevier; 2013:381-434.

27. Jang MY, Lee YL, Long CY, Chen HC et al. The protective effect of green tea catechins on ketamineinduced cystitis in a rat model. Urological Science 2015;26:86-192.

28. Wang Q, Wu Q, Wang J, Chen Y et al. Ketamine analog methoxetamine induced inflammation and dysfunction of bladder in rats. Int. J. Mol. Sci. 2017;18;(117):1-17.

29. Ramadan WS and Al-Hekry AH. Effect of Lepidium sativum on the structure of the urinary bladder in experimentally menopaused albino rats. Egyptian Journal of Histology 2013;36:379-388.

30. Mohamed EM, Abd El-Baset S A, AbdulMaksoud RS, Kattaia AA. Correlation between morphological and molecular changes in a rat model of partial urinary bladder obstruction and the potential effect of kaempferol. Int. J. Clin. Exp. Pathol. 2016;9;(10):10080-10092.

31. Zheng X, Jia B, Song X, Kong QY et al. Preventive potential of resveratrol in carcinogen-induced rat thyroid tumorigenesis. Nutrients 2018;10;(279):1-14.

32. El-Shahat MA and Erfan OS. The possible protective effect of metformin on acute experimental colitis induced by dextran sodium sulfate in mice: an immunohistochemical study. Egyptian Journal of Histology 2015;38:594-604.

33. Chauhan P, Sharma H, Singh S, Gupta YK, Kumar U. Attenuation of methotrexate-induced hepatorenal damage by Terminalia Bellerica fruit extract in experimental rats. Phoog. Res. 2018;10;(3):301-308.

34. Kabil SL. Diacerein ameliorates liver ischemia reperfusion insult in rats. Egyptian Journal of Basic and Clinical Pharmacology 2018;8:1-14.

35. Haiba DA and Ibrahim MA. Role of dexamethasone alone and in combination with quercetin in the urinary bladder after administration of ifosfamide: a histological, immunohistochemical, and morphometric study. Egyptian Journal of Histology 2015;38: 196-209.

36. Mostafa HK, Hamam GG. Aly El-Waseef DA. The possible protective role of 6-gingerol on a model of hepatic injury induced by carbon tetrachloride in adult male albino rats: Histological and immunohistochemical study. Egyptian Journal of Histology 2018; 40;(3):499-511.

37. Ghafeer HH, El-Gamal DA, Mohamed NA and Hassanin AI. Histological study of human abdominal skin after repeated pregnancy. Egyptian Journal of Histology 2015; 38:41-56.

38. Khalaf G, Shaker SM, and Kamal KM. Histological and immunohistochemical study on the musculosa of the urinary bladder in orchiectomized adult albino rats. Egyptian Journal of Histology 2014;37: 720-728.

39. Baker SC, Stahlschmidt J, Oxley J, Hinley J, Eardley I et al. Nerve hyperplasia: a unique feature of ketamine cystitis. Acta Neuropathologica Communications 2013;1;(64):1-7.

40. Omar SM and Raafat MH. Effect of partial bladder outlet obstruction on the rat urinary bladder and the possible role of curcumin on Aquaporin 1 expression: a light and electron microscopic study. Egyptian Journal of Histology 2014;37:689-700.

41. Shen CH, Wang ST, Lee YR, Liu SY. Biological effect of ketamine in urothelial cell lines and global gene expression analysis in the bladders of ketamine injected mice. Molecular Medicine Reports2015;11:887-895.

42. Lee WC, Su CH, Tain YL, Tsai CN et al. Potential orphan drug therapy of intravesical liposomal on a botulinum toxin-A for ketamine-induced cystitis by mucosal protection and anti-inflammation in a rat model. Scientific Reports 2018;8;(5795):1-9.

43. Jhang JF, Lin TY, Kuo HC. Intravesical injections of platelet-rich plasma is effective and safe in treatment of interstitial cystitis refractory to conventional treatment-A prospective clinical trial. Neurourology and Urodynamics. 2019; 38:703-709.

44. Moghadam A, Khozani TT, Mafi A,Namavar MR et al. Effects of platelet-rich plasma on kidney regeneration in gentamicin-induced nephrotoxicity. J. Korean Med. Sci. $2017 ; 32: 13-21$.

45. Marini MG, Perrini C, Esposti $\mathrm{P}$, Corradetti B et al. Effects of platelet-rich plasma in a model of bovine endometrial inflammation in vitro. Reproductive Biology and Endocrinology 2016;14;(58):1-17.

46. Martín-Solé O, Rodó J, García-Aparicio L, Blanch J, 
Cusí V, Albert A. Effects of platelet-rich plasma (prp) on a model of renal ischemia- reperfusion in rats. PLoS ONE 2016;11;(8):1-16.

47. Borrione P, Grasso L, Chierto E, Geuna S, Racca S et al. Experimental model for the study of the effects of platelet-rich plasma on the early phases of muscle healing. Blood Transfus. 2014;12;(1):s221-228.

48. Attia MG, Atef $\mathrm{H}$ and Elmansy RA. Autologous platelet rich plasma enhances satellite cells expression of Myo D and exerts angiogenic and antifibrotic effects in experimental rat model of traumatic skeletal muscle injury. Egyptian Journal of Histology 2018;40;(4):443-458.

49. Cervigni M. Interstitial cystitis/bladder pain syndrome and glycosaminoglycans replacement therapy. Translational Andrology and Urology 2015;4;(6): 638-642. 
الملخص العربى

\title{
تقييم تأثير البلازما الغتية بالصفائح الاموية وحمض الهيالورونيك على التهاب المثانة المستحدث بالكيتامين في الجرذان البيضاء: دراسة هستولوجية وهستوكميائية وائه مناعية
}

\author{
نهلة العراقي العزبـ- عبير مصطفي المحلاوي- علا مصطفي

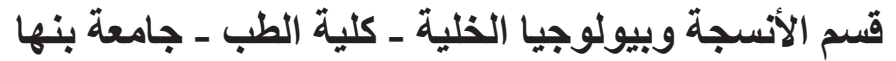

المقدمة: يحدث التهاب المثانة الناتج عن الكيتامين بشكل شائع لدى الأفر اد الذين يسرفون في استخدام الكيتامين. ويرتبط هذا الالتهاب مع تلف في بطانة المثانة وأعراض المسالك البولية السفلى. تعتبر البلازما الغنية بالصفائح الدموية هو خط علاجي جذاب في الطب التجديدي. وحمض الهيالورونيك له العديد من الآثار المفيدة في علاج أنواع مختلفة من التهابات المثانة.

الهُف من البحث: تقييم تأثثير البلازما الغنية بالصفائح الدموية و حمض الهيالورونيك على التهاب المثانة المستحدث بالكيتامين في ذكور الجرذان البالغين. الطريقة وخطة العمل: تم تقسيم ثمانية وأربعون من ذكور الجرذان البالغين إلى خمس مجمو عات: المجموعة الأولى: الجرذان الضابطة. المجموعة الثانية: مجموعة الكيتامين. المجموعة الثالثة: مجموعة الكيتامين التي تركت للتشافي. المجموعة الرابعة: مجموعة الكيتامين المعالجة بالبلازما الغنية بالصفائح الدموية. المجموعة الخامسة: مجموعة الكيتامين المعالجة بحمض الهيالورونيك. وقد أخذت عينات من جسم المثانة البولية وتمت معالجتها باستخدام التقنيات الهستولوجية و الهستوكيميائية المناعية. و أجريت الدراسات المورفومترية و التحليل الإحصائي. نتائج البحث: وقد أظهرت الدر اسة للمجموعتين الثانية و الثالثة وجود مساحات بؤرية من التحلل و التقرح مع نقص ظاهري في سمك الظهارة البولية. ولوحظ أيضا ارتشاح خلوي و احتقان بالأوعية الدموية المتسعة في أسفل ظهارة المثانة. وظهرت زيادة ذات دلالة احصائية في ألياف الكو لاجين في أسفل ظهارة المثانة وبين حزم العضلات. بينما كانت هناك زيادة ذات دلالة احصائية في التفاعل المناعي لصبغة NF-KB، وكانت هنالك زيادة ليس لها دلالة احصائية في الصبغات الهستوكيميائية المناعية للنوي ضد بروتين تكاثر الخلايا (PCNC) في ظهارة المثانة. ونقص ذو دلالة احصائية في الدسمين ، مقارنة بالمجموعة الأولى ـ في حين أظهرث المجمو عتين الر ابعة و الخامسة تحسنا في معظم التغير ات الهستولوجية و الهستوكميائيه مناعية التي وصفت سابقا. الاستنتاج: إن حقن البلازما الغنية بالصفائح الدموية و حمض الهيالورونيك في المثانة يوفر نأثثرًا إيجابيًا على علاج التهاب المثانة المستحدث بالكيتامين. وأن العلاج بحمض الهيالورونيك هو وسيلة أكثر فاعلية حيث أنه يوفر تحسنًا أفضل في شفاء خلايا الظهارة البولية ويشجع على تجدد الأنسجة بشكل أسرع. 